\title{
Non-surgical treatment of knee osteoarthritis
}

\author{
HS Kan, PK Chan *, KY Chiu, CH Yan, SS Yeung, YL Ng, KW Shiu, Tegan Ho
}

This article was published on $28 \mathrm{Mar}$ 2019 at www.hkmj.org.

\section{A B S T R A C T}

Knee osteoarthritis is one of the most common degenerative diseases causing disability in elderly patients. Osteoarthritis is an increasing problem for ageing populations, such as that in Hong Kong. It is important for guidelines to be kept up to date with the best evidence-based osteoarthritis management practices available. The aim of this study was to review the current literature and international guidelines on non-surgical treatments for knee osteoarthritis and compared these with the current guidelines in Hong Kong, which were proposed in 2005. Internationally, exercise programmes for non-surgical management of osteoarthritis have been proven effective, and a pilot programme in Hong Kong for comprehensive non-surgical knee osteoarthritis management has been successful. Long-term studies on the effectiveness of such exercise programmes are required, to inform future changes to guidelines on osteoarthritis management.
Hong Kong Med J 2019;25:127-33

https://doi.org/10.12809/hkmj187600

\section{${ }^{1}$ HS Kan}

${ }^{2}$ PK Chan *, FHKCOS, FHKAM (Orthopaedic Surgery)

${ }^{1} \mathrm{CH}$ Yan, FHKCOS, FHKAM (Orthopaedic Surgery)

${ }^{1}$ KY Chiu, FHKCOS, FHKAM (Orthopaedic Surgery)

${ }^{3}$ SS Yeung, MScHC(PT), PDPT

${ }^{4} \mathrm{YL} \mathrm{Ng}, \mathrm{BSc}, \mathrm{MHSc}$

${ }^{5}$ KW Shiu, BNurs(Aust)

${ }^{1} \mathrm{~T}$ Ho, BMedSc

Department of Orthopaedics and Traumatology, The University of Hong Kong, Pokfulam, Hong Kong

2 Department of Orthopaedics and Traumatology, Queen Mary Hospital, Pokfulam, Hong Kong

${ }^{3}$ Department of Physiotherapy, MacLehose Medical Rehabilitation Centre, Pokfulam, Hong Kong

${ }^{4}$ Department of Occupational Therapy, MacLehose Medical Rehabilitation Centre, Pokfulam, Hong Kong

${ }^{5}$ Department of Nursing, MacLehose Medical Rehabilitation Centre, Pokfulam, Hong Kong

* Corresponding author: lewis@ortho.hku.hk

\section{Introduction}

Conventionally, osteoarthritis (OA) is considered as progressive wear and tear of articular cartilage. However, recent evidence has suggested that it is an inflammatory disease of the entire synovial joint, comprising not only mechanical degeneration of articular cartilage but also concomitant structural and functional change of the entire joint, including the synovium, meniscus (in the knee), periarticular ligament, and subchondral bone. ${ }^{1}$

Knee osteoarthritis (KOA) is one of the most common degenerative diseases that causes disability in elderly people. An epidemiological study by Felson et $\mathrm{al}^{2}$ showed that about $30 \%$ of all adults have radiological signs of OA; $8.9 \%$ of the adult population has clinically significant $O A$ of the knee or hip, of which KOA was the most common type. Another study also showed that the likelihood of OA increases with age. ${ }^{3}$ The Chinese population has a similar prevalence rate. A nationwide populationbased study in China showed an $8.1 \%$ total incidence rate of symptomatic $\mathrm{KOA}$ and increasing prevalence of KOA with age. ${ }^{4}$ A study in Hong Kong showed that $7 \%$ of men and $13 \%$ of women had KOA..$^{5}$ It is estimated that the percentage of older adults in the Hong Kong population will increase from $16.6 \%$ in 2016 to $31.1 \%$ by $2036 .{ }^{6}$

Although clinical guidelines for managing lower limb osteoarthritis (LLOA) in the primary care setting were proposed in Hong Kong in 2004, ${ }^{7}$ comparison with recently updated international guidelines shows some differences from management in Hong Kong.

In ageing populations, such as that in Hong Kong, the prevalence of OA is expected to increase. Therefore, it is of paramount importance to keep updating OA management guidelines so as to provide the best possible evidence-based management in the primary setting. This may help to delay progression into end-stage OA and thus decrease the need for arthroplasty and alleviate long waiting times (the average waiting time for arthroplasty in public hospitals in Hong Kong is 66 months). ${ }^{5}$ The aim of the present study was to compare and contrast the LLOA management guidelines proposed in Hong Kong ${ }^{7}$ with international guidelines, including the Osteoarthritis Research Society International (OARSI), ${ }^{8}$ the American Academy of Orthopedic Surgeons (AAOS), ${ }^{9}$ and the American College of Rheumatology (ACR) [Table 1]. ${ }^{10}$

\section{Overview of treatment of knee osteoarthritis}

Treatment of KOA can be divided into nonsurgical or surgical treatment. Non-surgical treatment comprises non-pharmacological and pharmacological treatment, and nonpharmacological treatment comprises core first- 


\section{膝關節炎的非手術治療}

\section{簡浩昇、陳秉強、曲廣運、忻振凱、楊信成、吳欣麗、} 蕭潔慧、何天勤

膝關節炎是導致老年患者致殘的最常見退化疾病之一。隨着人口老 化, 骨關節炎的問題日益嚴重, 在香港也是如此。重要的是, 應確保 香港治療指南與骨關節炎治療的最佳循證實踐一致。本研究旨在回顧 膝關節炎非手術治療的當前文獻和國際指南, 並將之與2005年提出的 香港現行指南進行比較。國際上, 針對骨關節炎非手術治療的活動方 案已被證實有效, 香港的綜合非手術膝關節炎管理試驗計劃亦取得成 功。需要對這些活動方案的有效性進行長期研究, 以便為將來對骨關 節炎管理指南的轉變提供參考。 be recommended. Recent studies have proven the significance of weight modification: evidence has shown that knee pain is reduced by over $50 \%$ after body weight reduction by around $10 \%,{ }^{13}$ and weight reduction may drop the risk of developing symptomatic KOA by $50 \% .^{2}$ It is expected that weight management would also be effective in Hong Kong. A local study investigating the risk factors of KOA showed that overweight was the greatest risk factor for KOA in Hong Kong and that $64 \%$ of the investigated Hong Kong patients with KOA were overweight. $^{5}$

\section{Exercise}

Exercise aims to reduce pain and improve general mobility and joint function; more intensive exercise can strengthen the muscle around the knee joint. Exercise is one form of first-line treatment advocated by the Hong Kong LLOA guidelines. There is no recommendation regarding the type of exercise to do, suggesting that it has lower efficacy in reduction of pain and disability compared with weight loss. Exercise is now universally recommended by the other international guidelines. Recent studies suggest the important role of exercise in OA management, and different types of exercise have different benefits in KOA treatment. Targeted strengthening exercises, aerobic exercise, stretching, and flexibility exercises are recommended by AAOS, ACR, and OARSI.

A meta-analysis found that land-based exercise (especially exercise like Tai Chi) has the strongly favourable benefits of improving pain and physical function in patients with $\mathrm{KOA}$; the duration and type of exercise programme in the meta-analyses varied widely, but the general components of the programmes are strength training, active range of motion exercise, and aerobic activity. Although positive results were obtained for land-based exercise, they did not favour any specific exercise regimen or duration. ${ }^{14}$

A study in 2016 found that water-based exercise has short-term benefits for function but minor benefits for pain. ${ }^{15}$ It is suggested for patients with functional or mobility limitations.

Strength training exercises include primarily resistance-based lower limb and quadriceps strengthening exercises. A meta-analysis in 2011 showed moderate benefits of reducing pain and improving physical function. However, the duration of exercise varied among these programmes. ${ }^{16}$

\section{Biomechanical intervention and walking canes}

Biomechanical intervention and walking canes are not included in the Hong Kong LLOA guidelines but are regarded as appropriate and effective by the OARSI guidelines. A literature review suggests that knee braces and foot orthoses could have a 
TABLE I. Summary table of comparison between the Hong Kong LLOA guidelines ${ }^{5}$ and the AAOS, ${ }^{9}$ the $A C R,{ }^{10}$ and the OARSI $^{8}$ guidelines

\begin{tabular}{|c|c|c|c|c|}
\hline & \multicolumn{4}{|c|}{ Guidelines } \\
\hline & Hong Kong LLOA & AAOS & ACR & OARSI \\
\hline Education & Recommended & $\begin{array}{l}\text { Not included in } \\
\text { recommendation }\end{array}$ & $\begin{array}{l}\text { Not included in } \\
\text { recommendation }\end{array}$ & Appropriate with moderate benefits \\
\hline Weight loss & $\begin{array}{l}\text { Strongly recommended, } \\
\text { especially in overweight } \\
\text { patients }\end{array}$ & $\begin{array}{l}\text { Moderate recommendation } \\
\text { for symptomatic KOA and } \\
\mathrm{BMI} \geq 25\end{array}$ & $\begin{array}{l}\text { Strongly recommended } \\
\text { for overweight patients }\end{array}$ & Appropriate for all patients \\
\hline Exercise & $\begin{array}{l}\text { Recommended for all } \\
\text { patients, with more effects } \\
\text { than weight loss; no } \\
\text { recommendation on types } \\
\text { of exercise }\end{array}$ & $\begin{array}{l}\text { Strongly recommended for } \\
\text { symptomatic KOA self- } \\
\text { management programmes, } \\
\text { strengthening, low-impact } \\
\text { aerobic exercise, and } \\
\text { neuromuscular education }\end{array}$ & $\begin{array}{l}\text { Aerobic, aquatic, or } \\
\text { resistance exercise are } \\
\text { strongly recommended }\end{array}$ & $\begin{array}{l}\text { Land-based and water-based } \\
\text { exercises and strength training are } \\
\text { appropriate with minor to moderate } \\
\text { effects }\end{array}$ \\
\hline $\begin{array}{l}\text { Biomechanical } \\
\text { intervention and } \\
\text { brace }\end{array}$ & Not included & $\begin{array}{l}\text { Inconclusive recommendation } \\
\text { for symptomatic KOA }\end{array}$ & $\begin{array}{l}\text { Conditionally } \\
\text { recommended for KOA }\end{array}$ & $\begin{array}{l}\text { Appropriate and effective for } \\
\text { improving joint pain, stiffness, drug } \\
\text { dosage, and physical function }\end{array}$ \\
\hline Paracetamol & $\begin{array}{l}\text { Recommended as first-line } \\
\text { treatment }\end{array}$ & $\begin{array}{l}\text { Inconclusive recommendation } \\
\text { for symptomatic KOA }\end{array}$ & $\begin{array}{l}\text { Recommended as first- } \\
\text { line treatment }\end{array}$ & $\begin{array}{l}\text { Appropriate for patients without } \\
\text { relevant co-morbidities and } \\
\text { uncertain for patients with relevant } \\
\text { co-morbidities }\end{array}$ \\
\hline NSAID & $\begin{array}{l}\text { As alternatives to } \\
\text { paracetamol }\end{array}$ & $\begin{array}{l}\text { Strongly recommended for } \\
\text { symptomatic KOA }\end{array}$ & $\begin{array}{l}\text { Conditionally } \\
\text { recommended for hand, } \\
\text { knee, and hip OA }\end{array}$ & $\begin{array}{l}\text { Recommended for patients with } \\
\text { symptomatic hip or knee OA at } \\
\text { the lowest effective dose, not } \\
\text { appropriate for patients with } \\
\text { relevant co-morbidities }\end{array}$ \\
\hline Topical NSAID & $\begin{array}{l}\text { Appropriate alternatives to } \\
\text { oral NSAIDs }\end{array}$ & $\begin{array}{l}\text { Strongly recommended for } \\
\text { symptomatic KOA }\end{array}$ & $\begin{array}{l}\text { Strongly recommended } \\
\text { over oral NSAIDs for } \\
\text { patients aged } \geq 75 \text { years }\end{array}$ & $\begin{array}{l}\text { Appropriate for KOA as per } \\
\text { scientific review, overall safer and } \\
\text { better tolerated than oral NSAIDs }\end{array}$ \\
\hline $\begin{array}{l}\text { Intra-articular } \\
\text { steroid }\end{array}$ & $\begin{array}{l}\text { Only for short-term pain } \\
\text { management }\end{array}$ & $\begin{array}{l}\text { Inconclusive recommendation } \\
\text { for symptomatic KOA }\end{array}$ & $\begin{array}{l}\text { Conditionally } \\
\text { recommended for hip and } \\
\text { KOA }\end{array}$ & $\begin{array}{l}\text { For short-term moderate-to-severe } \\
\text { pain when oral analgesics and anti- } \\
\text { inflammatory agents fail, but should } \\
\text { consider alternatives for long-term } \\
\text { treatment }\end{array}$ \\
\hline $\begin{array}{l}\text { Intra-articular } \\
\text { hyaluronic acid }\end{array}$ & $\begin{array}{l}\text { Recommended for both } \\
\text { pain and functional } \\
\text { management }\end{array}$ & Strongly not recommended & No recommendation & $\begin{array}{l}\text { Uncertain for KOA and not } \\
\text { appropriate for multiple-joint OA }\end{array}$ \\
\hline Glucosamine & $\begin{array}{l}\text { Appropriate as an } \\
\text { alternative for moderate-to- } \\
\text { severe pain }\end{array}$ & Strongly not recommended & Not recommended & $\begin{array}{l}\text { Not appropriate for all patients when } \\
\text { used for disease modification and } \\
\text { uncertain for all patients when used } \\
\text { for symptom relief }\end{array}$ \\
\hline Opioid & $\begin{array}{l}\text { Considered if both } \\
\text { paracetamol and NSAID } \\
\text { failed or contra-indicated }\end{array}$ & $\begin{array}{l}\text { Inconclusive recommendation } \\
\text { for symptomatic KOA }\end{array}$ & $\begin{array}{l}\text { Conditionally } \\
\text { recommended for failed } \\
\text { initial therapy }\end{array}$ & $\begin{array}{l}\text { Uncertain recommendation because } \\
\text { of increased risk of severe side- } \\
\text { effects }\end{array}$ \\
\hline Duloxetine & $\begin{array}{l}\text { Not included in } \\
\text { recommendation }\end{array}$ & $\begin{array}{l}\text { Not included in } \\
\text { recommendation }\end{array}$ & $\begin{array}{l}\text { Conditionally } \\
\text { recommended for } \\
\text { patients aged } \geq 75 \text { years }\end{array}$ & $\begin{array}{l}\text { Included in the latest } 2010 \text { guideline } \\
\text { for patients without co-morbidities } \\
\text { nor multiple-joint involvement }\end{array}$ \\
\hline
\end{tabular}

Abbreviations: $\mathrm{AAOS}=$ American Academy of Orthopedic Surgeons; $\mathrm{ACR}=$ American College of Rheumatology; BMI = body mass index; KOA = knee osteoarthritis; LLOA = lower limb osteoarthritis; NSAID = non-steroidal anti-inflammatory drug; OA = osteoarthritis; OARSI = Osteoarthritis Research Society International

positive impact on decreasing pain and stiffness and improving physical function. However, conclusions about their effectiveness have yet to be made because of the lack of clinical trials and the heterogeneity of interventions among the studies reviewed. ${ }^{17}$ Both the OARSI and ACR guidelines suggest that walking canes are appropriate for KOA but not appropriate for multi-joint OA because they may increase weight loading on other affected joints. ${ }^{18}$ In contrast, the AAOS guidelines are inconclusive about this topic.

\section{Pharmacological treatment of knee osteoarthritis}

\section{Paracetamol}

The Hong Kong LLOA guidelines stipulate that paracetamol is a key medication for knee OA. It is regarded as the first-line treatment for mild to moderate OA pain because of its efficacy, safety, and cost, and it is also the preferred essential component of long-term pain control. However, 


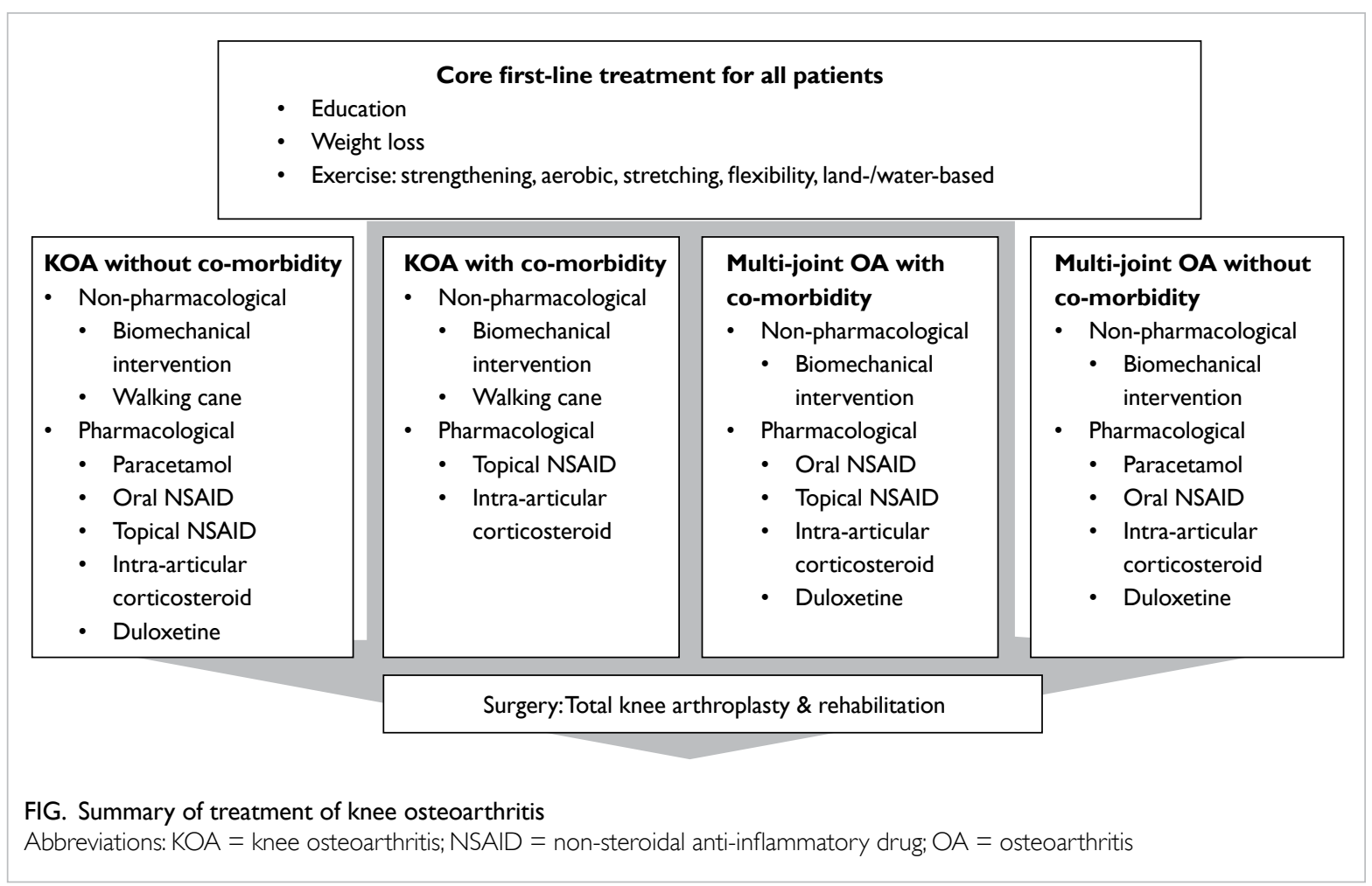

it is no longer the first-line treatment suggested by OARSI, as a meta-analysis showed that paracetamol has low efficacy for pain management. ${ }^{19}$ The OARSI guidelines recommend that paracetamol be given in conservative doses and durations, as there is concern regarding an increasing risk of gastrointestinal disturbance and multi-organ failure. ${ }^{20}$

\section{Non-steroidal anti-inflammatory drugs}

The Hong Kong LLOA and ACR guidelines suggest NSAIDs as an alternative to paracetamol, whereas the OARSI guidelines suggest NSAIDs as the preferred first-line pharmacological treatment, because systematic reviews have found that NSAIDs are superior to paracetamol for resting and overall pain. $^{21}$ Although NSAIDs are recommended in patients without risk, OARSI is reserved in its recommendation for NSAID use in patients with a high risk of co-morbidities. Non-selective NSAIDs have greater associated upper gastrointestinal risks, whereas selective NSAIDs have more cardiovascular side-effects like myocardial infarction; in addition, both selective and non-selective NSAIDs cause sideeffects like hypertension, congestive heart failure, and renal toxicity. The AAOS recommendations about NSAIDs are inconclusive for symptomatic KOA. The Hong Kong LLOA guidelines and all international guidelines strongly suggest that topical NSAIDs (eg, topical diclofenac) be considered as an option for knee-only OA, but their applicability for multiple joint OA is still uncertain. Both topical and oral NSAIDs have similar efficacy and significant benefits over placebo. Topical ones have less gastrointestinal risk but a higher risk of dermatological side-effects. ${ }^{22}$

\section{Intra-articular steroids}

The Hong Kong LLOA, ACR, and OARSI guidelines recommend that steroids only be used in acute exacerbations of joint inflammation, as frequent use can result in cartilage or joint damage and increase infection risk. The AAOS recommendation on this topic is inconclusive.

\section{Intra-articular hyaluronic acid}

The Hong Kong LLOA guidelines recommend hyaluronic acid for management of KOA for both pain reduction and functional improvement, as it is considered to have effects comparable to those of oral NSAIDs or steroid injections. However, the AAOS and ACR guidelines do not recommend the use of hyaluronic acid because of the lack of data from randomised controlled trials on either its benefits or safety. The OARSI recommendation is also uncertain because of the inconclusive results of recent meta-analyses. A meta-analysis with blinded trials found only small benefits for pain. ${ }^{23}$

\section{Glucosamine}

The Hong Kong LLOA guidelines consider glucosamine to have moderate to large effects on 
pain and disability in LLOA compared with placebo, and it is associated with few side-effects. It is used commonly as an alternative treatment, especially for mild to moderate KOA. However, all the international guidelines strongly recommend against the use of glucosamine because recent randomised controlled trials showed similar effects to placebo, with independent trials showing smaller effects than commercially funded ones. ${ }^{24}$

\section{Opioids}

In Hong Kong, opioid analgesics are considered if paracetamol is inadequate and NSAIDs are contraindicated, ineffective, or poorly tolerated. The ACR also suggested that opioids may be an alternative in failed initial therapy. However, with reference to international guidelines for OA management, we should consider the long-term overall usefulness of opioids. Although they have benefits for pain and physical function, compared with those who are not, patients taking opioids have a chance of adverse withdrawal effects that is 4 times higher, and a risk of developing serious side events, including fractures and cardiovascular events, that is 3 times higher. ${ }^{25}$ International guidelines provide a similar recommendation, AAOS makes an inconclusive recommendation, and OARSI is uncertain about opioid use because of the increased risk of sideeffects.

\section{Duloxetine}

The use of duloxetine is not suggested by the Hong Kong LLOA guidelines or AAOS. However, OARSI and AAOS suggest that co-existing depression and neuropathic pain contribute to the overall pain syndrome, as the pain experienced in OA is multifactorial. A study showed that duloxetine has pain reduction benefits over placebo. ${ }^{26}$ Therefore, it is recommended as a potential adjunct to conventional OA treatment for pain reduction. ${ }^{27}$

TABLE 2. Comparison between Hong Kong $\left(C O M E^{31}\right)$ and international exercise programmes $\left(O A C C P,{ }^{28} B O A,{ }^{29} \mathrm{GLA}^{2} \mathrm{D}^{30}\right)$

\begin{tabular}{|c|c|c|c|c|c|}
\hline Programme & $\begin{array}{l}\text { Target } \\
\text { OA }\end{array}$ & Targeted intervention & Duration & Outcome & $\begin{array}{l}\text { No. of patients } \\
\text { enrolled }\end{array}$ \\
\hline $\begin{array}{l}\text { COME } \\
\text { (Hong Kong) }\end{array}$ & Knee OA & $\begin{array}{l}\text { 3-Hour nurse-led education session, } \\
12 \text { sessions of physiotherapists- } \\
\text { supervised exercises; and 5-8 } \\
\text { sessions of occupational therapist-led } \\
\text { management programme with emphasis } \\
\text { on disease coping strategies and fatigue } \\
\text { management }\end{array}$ & $\begin{array}{l}6 \text { Weeks; follow- } \\
\text { up at } 6 \text { weeks, } \\
3 \text { months, and } \\
1 \text { year }\end{array}$ & $\begin{array}{l}\text { Improved pain, physical function, } \\
\text { physical activity, and quality of life at } \\
\text { both short- and long-term compared } \\
\text { with baseline }\end{array}$ & 50 since 2016 \\
\hline $\begin{array}{l}\text { OACCP } \\
\text { (Australia) }\end{array}$ & $\begin{array}{l}\text { Hip, knee } \\
\text { OA }\end{array}$ & $\begin{array}{l}\text { Coordinated multidisciplinary } \\
\text { management including exercise, diet, } \\
\text { psychological support, occupational } \\
\text { therapy, orthotics, and medical } \\
\text { management }\end{array}$ & Up to 12 months & $\begin{array}{l}\text { Significantly improves clinical outcomes } \\
\text { (ie, functionality, mobility, and pain) in } \\
\text { knee OA but modest benefits for hip OA. } \\
\text { Hospital running OACCP has less length } \\
\text { of stay for knee and hip replacement } \\
\text { separations than other hospitals have. } \\
11 \% \text { of Knee and } 4 \% \text { of hip OA } \\
\text { participants who had been waiting for } \\
\text { joint replacement surgery agreed that } \\
\text { they no longer need surgery. } \\
\text { Correlated with a slight reduction in the } \\
\text { likelihood of a patient being diagnosed } \\
\text { with obesity or hypertension. }\end{array}$ & $\begin{array}{l}\sim 10000 \text { since } \\
2012\end{array}$ \\
\hline $\begin{array}{l}\text { BOA } \\
\text { (Sweden) }\end{array}$ & $\begin{array}{l}\text { Hip, knee, } \\
\text { hand OA }\end{array}$ & $\begin{array}{l}\text { Physical therapist, occupational } \\
\text { therapist, and OA communicator (ie, } \\
\text { "expert patient") delivered education, } \\
\text { supported self-management, physical } \\
\text { activity recommendations, optional } \\
\text { individualised exercise programmes, } \\
\text { and optional supervised exercise group } \\
\text { sessions (using individual programmes) }\end{array}$ & $\begin{array}{l}3 \text { Months, follow- } \\
\text { up at } 12 \text { months }\end{array}$ & $\begin{array}{l}94 \% \text { Rated the programme as good/very } \\
\text { good, whereas } 62 \% \text { reported daily use } \\
\text { of what they learnt during the course, } \\
\text { and } 91 \% \text { reported weekly use after } 3 \\
\text { months; compliance was } 37 \% \text { and } 72 \% \text {, } \\
\text { respectively after } 12 \text { months }\end{array}$ & $\begin{array}{l}\sim 60000 \text { since } \\
2010\end{array}$ \\
\hline $\begin{array}{l}\text { GLA:D } \\
\text { (Denmark) }\end{array}$ & $\begin{array}{l}\text { Hip, knee } \\
\text { OA }\end{array}$ & $\begin{array}{l}\text { Physical therapists trained according } \\
\text { to clinical guidelines, patient education } \\
\text { includes } 2 \text { sessions of physical therapist- } \\
\text { delivered information, supported } \\
\text { self-management, physical activity } \\
\text { recommendations, and } 12 \text { supervised } \\
\text { neuromuscular exercise sessions; } \\
\text { immediate follow-up and additional } \\
\text { online follow-up at } 12 \text { months for data } \\
\text { collection and evaluation of results }\end{array}$ & $\begin{array}{l}3 \text { Months, follow- } \\
\text { up online at } 12 \\
\text { months }\end{array}$ & $\begin{array}{l}\text { Data collected from } 9825 \text { participants } \\
\text { and results showed improvement in pain } \\
\text { intensity, quality of life, physical function, } \\
\text { and activity at } 3 \text { months of participation; } \\
\text { fewer participants were on painkillers } \\
\text { and sick leave by } 12 \text { months }\end{array}$ & $\begin{array}{l}\sim 15000 \text { since } \\
\text { February } 2013\end{array}$ \\
\hline
\end{tabular}

Abbreviations: BOA = Better management of patient with OsteoArthritis; COME = Comprehensive Osteoarthritis ManagEment; GLA:D = Good Life with Arthritis in Denmark; OA = osteoarthritis; OACCP = Osteoarthritis Chronic Care Program 


\section{Models of knee osteoarthritis management and comparison}

As mentioned above, an increasing number of studies has proven the effectiveness of exercise and physiotherapy on OA management; with the increasing ageing of the population, it would be ideal for Hong Kong to develop a well-established exercise programme for patients with $\mathrm{OA}$ as both a nonsurgical treatment and follow-up. There have already been different well-established exercise programmes for non-surgical OA management throughout the world, and they have achieved great outcomes. Successful examples include the Osteoarthritis Chronic Care Program in Australia (OACCP), ${ }^{28}$ Better management of patients with OsteoArthritis in Sweden, ${ }^{29}$ and Good Life with osteoArthritis in Denmark (Table 2).$^{30}$ All of these programmes have been proven to improve patients' pain, mobility, physical function, and quality of life. The OACCP has also proven that an exercise programme helps to decrease the demand for arthroplasty; $11 \%$ of knee and $4 \%$ of hip OA participants who had been waiting for arthroplasty agreed they no longer needed surgery. Different programmes may have minor arrangements targeting their patients, but their content and training duration are generally similar; these programmes consist of education delivered by

TABLE 3. Patients receiving Comprehensive Osteoarthritis ManagEment (COME) showed consecutive significant improvements over each assessment time point $(n=55) * 31$

\begin{tabular}{|c|c|c|c|c|}
\hline & \multicolumn{4}{|c|}{ Data } \\
\hline Age (years) & \multicolumn{4}{|c|}{$63.3 \pm 7.4$} \\
\hline \multicolumn{5}{|l|}{ Gender } \\
\hline Male & & 1 & 3 & \\
\hline \multirow[t]{2}{*}{ Female } & \multicolumn{4}{|c|}{42} \\
\hline & Baseline & 6 Weeks & 3 Months & 12 Months \\
\hline PSEQ score & $42 \pm 11.2$ & $46.7 \pm 10 \dagger$ & & \\
\hline FACIT score & $34.4 \pm 8.5$ & $38.4 \pm 7.1 \ddagger$ & & \\
\hline $\begin{array}{l}\text { One-minute chair test } \\
\text { repetitions }\end{array}$ & $26.8 \pm 11.3$ & $35.5 \pm 12.2 \ddagger$ & $38.1 \pm 11.1 \ddagger$ & \\
\hline $\begin{array}{l}\text { Right quadriceps } \\
\text { strength }(\mathrm{kg})\end{array}$ & $25.6 \pm 8.9$ & $29.9 \pm 9.9 \ddagger$ & $31.1 \pm 11.0 \ddagger$ & \\
\hline $\begin{array}{l}\text { Left quadriceps } \\
\text { strength }(\mathrm{kg})\end{array}$ & $24.8 \pm 9.2$ & $28.0 \pm 9.2 \ddagger$ & $30.5 \pm 10.4 \ddagger$ & \\
\hline PSFS score & $3.5 \pm 2.3$ & $6.7 \pm 1.8 \ddagger$ & $6.8 \pm 1.8 \ddagger$ & $6.7 \pm 1.9 \ddagger$ \\
\hline SEE-C score & $47.3 \pm 14.0$ & $64.9 \pm 11.1 \ddagger$ & $65.2 \pm 12.4 \ddagger$ & $62.0 \pm 17.6 \ddagger$ \\
\hline $\begin{array}{l}\text { Weekly time spent for } \\
\text { exercise (mins) }\end{array}$ & $58.4 \pm 44.9$ & $81.8 \pm 50.5 \ddagger$ & $88.4 \pm 33.8 \ddagger$ & $107.5 \pm 26.3 \ddagger$ \\
\hline \multicolumn{5}{|c|}{$\begin{array}{l}\text { Abbreviations: ACIT = Functional Assessment of Chronic Illness Therapy; PSEQ = Pain } \\
\text { Self-Efficacy Questionnaire; PSFS = Patient-Specific Functional Scale; SEE-C = Chinese } \\
\text { version of Self-Efficacy of Exercise } \\
* \text { Data are shown as mean } \pm \text { standard deviation, unless otherwise specified } \\
\dagger P<0.005 \\
\neq P<0.001\end{array}$} \\
\hline
\end{tabular}

physiotherapists and sharing from "expert" patients, supported self-management, and supervised neuromuscular exercise sessions of progressive intensity. These programmes usually last at least 3 months with follow-up for 12 months.

Comprehensive Osteoarthritis ManagEment (COME) initiated in 2016 is a pioneering programme for Hong Kong. ${ }^{31}$ The COME programme is a multidisciplinary exercise programme for nonsurgical KOA that consists of a 6-week intensive training programme: the components include a 3-hour nurse-led education session, 12 sessions of physiotherapist-supervised exercises; and five to eight sessions of an occupational therapist-led management programme with emphasis on disease coping strategies and fatigue management. After 1 year, patients enrolled in the COME programme reported short-term improvement in Pain SelfEfficacy Questionnaire, Functional Assessment of Chronic Illness Therapy-Fatigue Scale, physical capacity assessed by quadriceps strength, and physical function assessed by one-minute chair test. One-year improvement showed in Patient-Specific Functional Scale, Chinese version of Self-Efficacy of Exercise, and weekly time spent for exercise (Table 3).

\section{Conclusion}

In ageing populations, the prevalence of $\mathrm{KOA}$ is expected to increase; thus, there is a need for consensus on non-surgical OA management, so as to improve outcomes for patients with $\mathrm{OA}$ and to decrease the burden of arthroplasty. Various exercise programmes for non-surgical OA management have been shown to be effective for improvement of pain, physical function, mobility, and quality of life, and these programmes have even decreased the need and waiting times for arthroplasty. Long-term follow-up of such exercise programmes should be considered to further assess their outcomes.

\section{Author contributions}

All authors had full access to the data, contributed to the study, approved the final version for publication, and take responsibility for its accuracy and integrity.

Concept or design: RHS Kan, PK Chan, KY Chiu, CH Yan. Acquisition of data: T Ho.

Analysis or interpretation of data: SS Yeung, YL Ng, KW Shiu. Drafting of the manuscript: RHS Kan.

Critical revision for important intellectual content: RHS Kan, PK Chan, KY Chiu, CH Yan, T Ho.

\section{Conflicts of interest}

No conflicts of interest are declared by the authors.

\section{Funding/support}

This research received no specific grant from any funding agency in the public, commercial, or not-for-profit sectors. 
References

1. Mobasheri A, Batt M. An update on the pathophysiology of osteoarthritis. Ann Phys Rehabil Med 2016;59:333-9.

2. Felson DT, Zhang Y, Anthony JM, Naimark A, Anderson JJ. Weight loss reduces the risk for symptomatic knee osteoarthritis in women. The Framingham Study. Ann Intern Med 1992;116:535-9.

3. Michael JW, Schlüter-Brust KU, Eysel P. The epidemiology, etiology, diagnosis, and treatment of osteoarthritis of the knee. Dtsch Arztebl Int 2010;107:152-62.

4. Tang X, Wang S, Zhang Y, Niu J, Tao K, Lin J. The prevalence of symptomatic knee osteoarthritis in China: results from China health and retirement longitudinal study. Osteoarthritis Cartilage 2015;23(Suppl 2):A176-7.

5. The Chinese University of Hong Kong. Osteoarthritis in Hong Kong Chinese-prevalence, aetiology and prevention. 2001. Available from: http://www.cuhk.edu. hk/ipro/010306e.htm. Accessed 14 Dec 2018.

6. Census and Statistics Department, Hong Kong SAR Government. Hong Kong population projections for 2017-2066. Available from: https://www.censtatd.gov.hk/ media_workers_corner/pc_rm/hkpp2017_2066/index.jsp. Accessed 14 Dec 2018.

7. Department of Community and Family Medicine, Chinese University of Hong Kong; Centre for Health Education and Health Promotion. Clinical guidelines for managing lowerlimb osteoarthritis in Hong Kong primary care setting. Department of Community and Family Medicine, Chinese University of Hong Kong; 2004.

8. McAlindon TE, Bannuru RR, Sullivan MC, et al. OARSI guidelines for the non-surgical management of knee osteoarthritis. Osteoarthritis Cartilage 2014;22:363-88.

9. Jevsevar DS. Treatment of osteoarthritis of the knee: evidence-based guideline, 2nd edition. J Am Acad Orthop Surg 2013;21:571-6.

10. Hochberg MC, Altman RD, April KT, et al. American College of Rheumatology 2012 recommendations for the use of nonpharmacologic and pharmacologic therapies in osteoarthritis of the hand, hip, and knee. Arthritis Care and Res (Hoboken) 2012;64:465-74.

11. Wluka AE, Lombard CB, Cicuttini FM. Tackling obesity in knee osteoarthritis. Nat Rev Rheumatol 2013;9:225-35.

12. Zheng $\mathrm{H}$, Chen C. Body mass index and risk of knee osteoarthritis: systematic review and meta-analysis of prospective studies. BMJ Open 2015;5:e007568.

13. Vincent HK, Heywood K, Connelly J, Hurley RW. Obesity and weight loss in the treatment and prevention of osteoarthritis. PM R 2012;4(5 Suppl):S59-67.

14. Kang JW, Lee MS, Posadzki P, Ernst E. T'ai chi for the treatment of osteoarthritis: a systematic review and metaanalysis. BMJ Open 2011;1:e000035.

15. Bartels EM, Juhl CB, Christensen R, et al. Aquatic exercise for the treatment of knee and hip osteoarthritis. Cochrane Database Syst Rev 2016;(3):CD005523.

16. Jansen MJ, Viechtbauer W, Lenssen AF, Hendriks EJ, de Bie RA. Strength training alone, exercise therapy alone, and exercise therapy with passive manual mobilisation each reduce pain and disability in people with knee osteoarthritis: a systematic review. J Physiother 2011;57:1120.

17. Raja K, Dewan N. Efficacy of knee braces and foot orthoses in conservative management of knee osteoarthritis: a systematic review. Am J Phys Med Rehabil 2011;90:247-62.

18. Jones A, Silva PG, Silva AC, et al. Impact of cane use on pain, function, general health and energy expenditure during gait in patients with knee osteoarthritis: a randomised controlled trial. Ann Rheum Dis 2012;71:172-9.

19. Bannuru RR, Dasi UR, McAlindon TE. Reassessing the role of acetaminophen in osteoarthritis: systematic review and meta-analysis. Osteoarthritis Cartilage 2010;18(Suppl 2):S250.

20. Craig DG, Bates CM, Davidson JS, Martin KG, Hayes PC, Simpson KJ. Staggered overdose pattern and delay to hospital presentation are associated with adverse outcomes following paracetamol-induced hepatotoxicity. $\mathrm{Br} J$ Clin Pharmacol 2012;73:285-94.

21. Towheed TE, Maxwell L, Judd MG, Catton M, Hochberg MC, Wells G. Acetaminophen for osteoarthritis. Cochrane Database Syst Rev 2006;(1):CD004257.

22. Chou R, Helfand M, Peterson K, Dana T, Roberts C. Comparative effectiveness and safety of analgesics for osteoarthritis. Rockville, MD: Agency for Healthcare Research and Quality (US); 2006.

23. Rutjes $A W$, Jüni $P$, da Costa $B R$, Trelle $S$, Nüesch $E$, Reichenbach S. Viscosupplementation for osteoarthritis of the knee: a systematic review and meta-analysis. Ann Intern Med 2012;157:180-91.

24. Zhang W, Nuki G, Moskowitz RW, et al. OARSI recommendations for the management of hip and knee osteoarthritis: part III: changes in evidence following systematic cumulative update of research published through January 2009. Osteoarthritis Cartilage 2010;18:476-99.

25. da Costa BR, Nüesch E, Kasteler R, et al. Oral or transdermal opioids for osteoarthritis of the knee or hip. Cochrane Database Syst Rev 2014;(9):CD003115

26. Chappell AS, Desaiah D, Liu-Seifert H, et al. A doubleblind, randomized, placebo-controlled study of the efficacy and safety of duloxetine for the treatment of chronic pain due to osteoarthritis of the knee. Pain Pract 2011;11:33-41.

27. Yu SP, Hunter DJ. Managing osteoarthritis. Aust Prescr 2015;38:115-9.

28. Deloitte Access Economics. Osteoarthritis Chronic Care Program evaluation. Agency for Clinical Innovation. 2014. Available from: https://www.aci.health.nsw.gov.au/_data/ assets/pdf_file/0009/259794/oaccp-evaluation-feb-2015. pdf. Accessed 15 Dec 2018.

29. Thorstensson CA, Garellick G, Rystedt H, Dahlberg LE. Better management of patients with OsteoArthritis: development and nationwide implementation of an evidence-based supported osteoarthritis self-management programme. Musculoskeletal Care 2015;13:67-75.

30. Skou ST, Roos EM. Good Life with osteoarthritis in Denmark (GLA: $\mathrm{D}^{\mathrm{TM}}$ ): a nationwide implementation of clinical recommendations of education and supervised exercise in knee and hip osteoarthritis. Osteoarthritis Cartilage 2017;25(Suppl 1):S389-90.

31. Chan PK, Yeung SS, Siu SW, et al. Comprehensive Osteoarthritis Management (COME) ProgrammeMultidisciplinary exercise training programme for patients with age-related osteoarthritis of knee. Hong Kong. Proceedings of the 13th International Symposium on Healthy Aging "Aging, Health, Happiness"; 2018 Mar 10-11; Hong Kong. Hong Kong: LKS Faculty of Medicine, The University of Hong Kong; 2018: 70. 